\title{
Customers' repurchase decision in the culinary industry: Do the Big-Five personality types matter?
}

\author{
Muhammad Ichwan Musa \\ Muhammad Ilham Wardhana Haeruddin \\ M. Ikhwan Maulana Haeruddin \\ Universitas Negeri Makassar, Indonesia
}

\section{Keywords}

The Big-Five personality types, repurchasing decision, social media, social status, qualitative method

\begin{abstract}
This paper aims to explore the Big-Five (5) personality types on customers' purchase decisions, as it is regarded within the phenomenon of customers' experienced meaning, which would shape how a person's personality would define their meaning of perceptions toward an experience in repurchasing decisions. A qualitative study with semi-structured interviews was employed in order to answer the research objectives by interviewing 84 customers in café and restaurants in Makassar city. In this paper it was discovered that participants whose high level of personality traits such as Openness, Conscientiousness and Agreeableness are the ones who will tend to make repurchase decision in the culinary industry. Moreover, those with low level in dimension of Neuroticism show a substantial relationship in making repurchase decision toward service/goods in culinary industry merely for identity making, particularly their social status in social media. Based on the research findings, there are several factors (themes) identified in exploring the relationship between the big-five personality types (Extraversion, Agreeableness, Conscientiousness, Neuroticism, and Openness to Experience) and repurchase decision in the culinary context. These are: 1) word of mouth and social status; and 2) price. This paper offers original contributions as this paper acknowledges the importance of a qualitative study in exploring the relationship between personality types and customers repurchase decision.
\end{abstract}

Corresponding author: Muhammad Ichwan Musa

Email address for corresponding author: m.ichwan.musa@unm.ac.id

First submission received: $15^{\text {th }}$ November 2017

Revised submission received: $16^{\text {th }}$ January 2018

Accepted: $25^{\text {th }}$ March 2018

\section{Introduction}

One of the characteristics of middle-class customers in marketing studies is marked by the shifting of consumption patterns. As the customers getting richer and well educated, then their patterns of consumption also begin to shift from 'goods-based consumption' to 'experience-based consumption' (Back, 2005). Experience-based consumption may include but not limited to: holiday vacation, staying at hotel, eating and hanging out at cafe/restaurant, watching movie/music concert, karaoke, gym, and wellness. These activities are strongly perceived will significantly influence their social status level. It is argued that the more positive experience that consumer's experience, the greater tendency for consumers to make repurchase decision. Customers repurchase decision topic has been widely discussed in the extant literatures (Fang, Chiu, \& Wang, 2011; Han \& Ryu, 2012; Kim \& Gupta, 2009; Seiders, Voss, Grewal, \& Godfrey, 2005), which not only covered issue on green marketing awareness effect on repurchase decision (Suki, 2013), on the word of mouth processes (Bansal \& Voyer, 2000), how male consumers' repurchase intention on cosmetic brands in South Africa context (Chinomona \& Maziriri, 2017), but also in gender differences on repurchase decision (Frank, Enkawa, \& Schvaneveldt, 2014). However, until now there are lacks literature that specifically discusses the relationship between customers' personality types and repurchase decision in a qualitative method context. A close attempt has been conducted by Barkhi \& Wallace (2007) and Bellamy \& Becker (2015). These studies explore the impact of personality type on purchasing decisions in virtual stores contexts by employing quantitative method. Why this study chooses 
qualitative stance? Because this paper aims to explore the personality type on customers' purchase decisions, as it is regarded within the phenomenon of customers' experienced meaning (Saunders et al., 2012), which would shape how a person's personality would define their meaning of perceptions toward an experience in purchasing decisions (Creswell, 2013).

\section{Literature Review}

\section{Customer's Repurchase intention}

Customer's repurchase intention is defined as the customer's preference and probability in consuming the previous service again in the future (Kotler, 2012). Once a costumer has considered all the choices and generates buying intention, it is argued that there could be only two factors that may influence the decision of the costumer of buying the service or product. Firstly, the perception and feedback of other costumers toward the similar service or product and secondly, it can be in the form of motivation level to comply or accept the feedback (Kotler et al., 2009). Along similar lines repurchase intention is understood as the repetitive process of purchasing services and goods from a particular seller (Hellier et al., 2003), in order to experience the post-shopping values. Furthermore, those two factors (Kotler et al., 2009) are argued significantly related with an individual's personality (Barkhi \& Wallace, 2007; Bellamy \& Becker, 2015; Haeruddin, 2017).

Also, customers' experiences in virtual transaction may differ with those in traditional transaction, particularly in-service sector. Customers may perceive that they should be present in situ to experience the service themselves, which also relates with to-see and to-be-seen customers' experiences (Marwick \& Boyd, 2011; Pine \& Gilmore, 1998). Therefore, based on the explanations, it is fair to argue that the customer's personality shapes their repurchase intention, which likely tend to influence how the customers will repurchase services/goods in the future.

\section{The Big Five Personality}

Personality defined as a set of stable traits (McShane, Olekalns, \& Travaglione, 2012), whereas the Big Five personality types are understood as the broad categories which have been widely explored in the literatures, particularly in psychology, management, and organization studies (Haeruddin \& Natsir, 2016; Gosling, Rentfrow, \& Swann, 2003; Barrick \& Mount, 1991). The Big Five personality traits are a hierarchal organization of personality traits which combined in to particular segment as proposed by McCrae \& John (1992) and developed by Wayne, Musisca, \& Fleeson (2004). According to Wayne, Musisca, \& Fleeson (2004), those traits are:

Openness $(O)$ to Experience/Intellect is a dimension that measures a person's adaptability rate. If a person's openness to experience level is high, then it can be perceived that this person tends to be open to new ideas, easy to tolerate change, and is happy with new experiences. On the other hand, if a person's openness to experience level is low, then this person can be categorized into Closed-Minded clusters, which are likely to be closed with new ideas. Conscientiousness $(C)$ is a personality dimension that measures a person's prudential level. If your Conscientiousness value is high, then you tend to do something with caution. People with Conscientiousness are tending to be organized and disciplined because of their caution. If your Conscientiousness value is low, then you go into the disorganized category that means it tends to be irregular or erratic.

Extraversion $(E)$ is a personality dimension that measures a person's level of openness. Ever heard of Extrovert and Introvert? This dimension is the dimension that discusses it. If your Extraversion score is high, then you are a person who has a high social level, easy going, happy to interact, and be friendly. In contrast, the low Extraversion value indicates that the person is entering introverted category where this person tends to be calm and does not have a high level of motivation in mingling in his/her social life.

Agreeableness (A) is a dimension that measures the level of one's friendliness. People with high Agreeableness values are usually described with someone who is helpful, forgiving, and compassionate. The low value of Agreeableness indicates that the person belongs to the Disagreeable group; the person with this type is the person who likes to give criticism, hard to cooperate because of the critical nature.

Neuroticism $(N)$ is a dimension that measures an individual's anxiety level. People with high values of Neuroticism tend to be more easily worried in their lives, emotionally unstable and easily feel insecure and because of this fear, people like this often have difficulty in relationships and commitments. 
Low values of Neuroticism enter the Calm / Relaxed class that makes people of this type tend to be happier and satisfied with life than people with high Neuroticism because they have a calm and relaxed nature.

A relevant study from Mulyanegara, Tsarenko, \& Anderson (2009) which focused on the Big Five dimensions in the context of fashion products discovered that several dimensions of these personality types are central in shaping preferences on particular dimensions of brand personality. This paper aims to extend their research findings by exploring the relationship between the 5 personality types and customer's repurchasing decision, particularly in the culinary industry.

\section{Research Methodology and Context}

This study employs qualitative method with interpretative stance. In order to obtain optimal data, authors employed a semi-structured interview and interviewed 84 customers who visited several prominent café and restaurant in the city of Makassar, Indonesia. Moreover, semi-structured interviews include an element of storytelling, where participants are asked to describe some specific moments, incidents, and activities in their personal purchasing experiences and the factors which motivating them to make a repurchase decision. Criteria of inclusion are those who are made repetitive purchase in a particular merchant (café \& restaurant) at least once. A qualitative research design was employed as it was significantly match with the research question and also to comprehend lived experiences and an understanding of the meanings of customers repurchase decision experiences. In average, the length of interview sessions is around 1.5 to 2 hours. The collected data are grouped into different themes and analyzed the data. In analyzing data, the authors were assigned to read and re-read the data in order to identify potential emerging themes. All of the authors came up with the similar emerging themes and collectively discussed on it whether to include the themes or not. While reading these various emerged themes, data saturation is reached on 84 participants, when there are no more emerging new themes or new information (Saunders et al., 2012).

The process of data analysis and emergence of themes was iterative. The data were coded and thematically analyzed using the Decision Explorer Software and NVivo computer software. Predominantly, participants are college students and employees on lower to middle management level, whose leisure budget average start from IDR 1.000.000 - 3.000.000 per month. Furthermore, most of them are women aged 17-25 years (early adult). Hailed as the largest city and as the gate of Eastern part in Indonesia, Makassar's economy depends on the service sector, which makes up approximately $70 \%$ of activity (Hasyim \& Unde, 2016). It is found that culinary industry and hotel services are the largest contributor $(29.14 \%)$, whereas transportation and communication' contribution is around $14.86 \%$, trading for 14.86, and finance around 10.58\% (Wardoyo \& Reza, 2016; Hasyim \& Unde, 2016). Along with the rise of social media and Internet usage in the last couple of years, modern life style in Makassar city has thrived particularly in culinary industry sector (Setiawan, Andjarwirawan, \& Handojo, 2013). It can be seen from the mushrooming café and restaurants in the city, which offered value-added through distinctive menus, tastes, concepts and themes, to attract customers (Jefry \& Aldianto, 2012).

\section{Results}

Based on the research findings, there are several factors (themes) identified in exploring the relationship between the big five personality types (Extraversion, Agreeableness, Conscientiousness, Neuroticism, and Openness to Experience) and repurchase decision in culinary context. These are: 1) Social media and social status; and 2) price. These factors will be elaborated in the following section.

\section{Social media and Social status}

Word of mouth is perceived as significant in influencing the repurchase decision among our participants. As most of our participants are categorized as early adult (17-25 years old), the power of peer in generating repurchase decision is dominant. For those in high level of Openness to experience, social media is the key in making repurchase decision as exemplified by the following quotes: 
You know what? This famous artist is the brand ambassador of this restaurant. She posts everything related to this restaurant in Instagram and she is very attractive, I think I will keep coming back to this restaurant because she is my idol (HIL, female, 22 yo, Part-time project officer).

This café used to be unknown to the city, but it became viral since the visit of the President of Indonesia to this café. Now everyone wants to go there, either just taking selfies, posting check-in, hashtagging, or just enjoy the view. Café life style is the current trend and I need to be able to keep updated so my friends won't call me outdated (PLF, male, 24 yo, Bank officer).

The power of viral and buzz marketing creates the word of mouth in the social media and it also creates peer pressure among participants. This would relate to the usage of social media in influencing their social status. According to the findings, participants with personality type of high level of Conscientiousness, high level of Extraversion, high level of Openness to Experience, high level of Agreeableness - exclusion for those whose low level of Neuroticism - mentioned that social status is key reason in doing repurchase decision in particular merchant. An interesting finding is found on those who are categorized as introvert (as opposite of extrovert, who are open to new experiences, easy going, and easy to interact) who also admit that social status is important in making repurchase decision. Despite the characteristics of the introvert persons is those who does not have high level in mingling in their social life, introvert customers are found being able to place themselves in a social place (café and restaurant) in order to "heighten our social status in social media" (RSF, female, 25 yo, Bank Officer). The power of social media is also holding a key role in this theme. All customers use social media platforms as Facebook, Path, and Instagram in order to post their activities (repurchase decision). By checking-in, posting pictures, hashtagging, and taking selfie/wefie with friends are perceived as the activities that would increase their social status in their social life as mentioned as follows:

I have my own hashtag with my gang, so every time we come back to this café we use the same hashtag to let everyone aware of our existence (JYU, female, 19 yo, college student).

Participants with low level of Neuroticism mentioned that they were not doing repurchase decision for the social status, but tend to be for personal satisfaction reason (inner peace \& being sentimental), as exemplified by the following quote:

Those people spend their money in this place just to get like on their Facebook and Instagram, (just) to get famous. Well, I am not that kind of people. I always come back to this place because it feels peace whenever I am here (UNF, female, 25 yo, middle manager).

Their food is junk, I did not come here for the food; I just came for check-in in this restaurant. I just order for the mineral water and that is my favorite menu in this place. I come here just to cherish my past memories with my late parents (FGY, female, 18 yo, college student).

An interesting finding also discovered in this research, as mentioned by FGY above, that the taste of the foods and drinks nor the social status did not have any influence in their repurchasing decision. It is should be highlighted that FGY is categorized under Introvert, low level of Openness to experience, and low level of Neuroticism.

\section{Price}

Furthermore, according to the analysis, price level of the services/goods is also contributing in making them repurchase decision. Despite most of our participants mentioned that their leisure budget range from IDR 1.000.000 - 3.000.000 per month, their choice of café and restaurant are irrational. Why irrational? Because some of them would spend more than their monthly budget in order to make them repurchase decision. For those categorized in high level of Openness to experience, they are willing to spend more money (mostly by using their credit cards), in making purchase decision. However, it should be noted that participants in this category are tends to be not loyal in particular brand because they are eager in seeking new experiences as exemplified by the following quote: 
I know I spent more than I can earn. But you know what, you only live once. So, I just want to enjoy my life while I can even though I have to spend more of my budget and using my credit cards and get valuable experiences from many purchased services and goods (ESL, female, 24 yo, entrepreneur).

In contrast, those who are categorized in low level of Openness to experience admitted that they are more cautious in spending their budget, because they only would like to spend their money to particular brand, therefore they are more loyal and tend to make repurchase decision.

I work hard to get money, so I won't waste it on the services and goods you do not know well. I only spent my money on stuffs I really know; even though their price is increased I won't mind spending my money here again. (CDL, female, 22 yo, Bank Officer).

Similarly, participants who fall into high level of conscientiousness mostly tend to be selective in making repurchase decision regarding price level. In contrast, those who are in low level of conscientiousness tend to be economically in their purchasing decision; they tend to be not loyal on the services and goods that are expensive and exceed their monthly budget, therefore repurchasing decision is not likely to happen.

\section{Discussion}

Due to the intensive use of Internet and social media, viral and buzz marketing are significant key factors in influencing our participants in this study in making repurchase decision. This is in line with the previous research (Van Vaerenbergh, Larivière, \& Vermeir, 2012; Spreng, Harrell, \& Mackoy, 1995; Vázquez-Casielles, Iglesias, \& Varela-Neira, 2017). Viral marketing is creating word of mouth and eventually lead to the social status among participants. However, there is lack of effort in connecting relationship between personality type and repurchase decision-making. In this study, in regard to social status, it was found that participants whose high level of personality traits such as Openness, Conscientiousness and Agreeableness are the ones that will tend to make repurchase decision in the culinary industry. Moreover, those with low level in dimension of Neuroticism show a substantial relationship in making repurchase decision toward particular service/goods in culinary industry, just to crafting their social status in social media. An exception is for those with low level of Neuroticism because they tend to be calm and have a relaxed nature. Additionally, in regard to the price, it was found that participants, regardless of their personality type, were irrational in their economic behavior, because some of them would spend more than their monthly budget in order to make their repurchase decision. For those categorized in high level of Openness to experience, they are willing to spend more money (mostly by using their credit cards), in making repurchase decision. However, it should be noted that participants in this category are tends to be not loyal in particular brand because they are eager in seeking new experiences.

On the other hand, those who are categorized in low level of Openness to experience admitted that they are more cautious in spending their budget, because they only would like to spend their money to particular brand, therefore they are more loyal and tend to make repurchase decision. This finding is different with Vázquez-Casielles, Iglesias, \& Varela-Neira's work (2017). Similarly, participants who fall into high level of conscientiousness mostly tend to be selective in making repurchase decision in regard to price level. In contrast, those who are in low level of conscientiousness tend to be economically in their repurchasing decision; they tend to be not loyal on the services and goods that are expensive and exceed their monthly budget, therefore repurchasing decision is not likely to happen. An intriguing finding is also discovered that most of the participants are women aged 17-25 years (early adult). This age group tend to be seeking new experiences and at the same time try to establish their identity by creating a sense of stability. This sense of stability can be characterized by their repurchase decision toward services/goods in the culinary industry.

\section{Implications}

The present study offers implications, both practical and theoretical. Firstly, for practical implications there will be effect on how personality type shape customers repurchase decision. It was found that most of the participants tend to make repurchase decision due to the social status and the influence of the social media. However, it is also found that the taste/menu of the foods \& drinks are not 
significant factor in making repurchasing decision. In order to tackle this matter, marketers or brand marketers should be aware on this issue, whether to improve the menu or offer such value added for customers. Brand marketers also should acknowledge the difference in personality type since their customers are varied in terms of personality. For theoretical implications, it should be addressed that personality has significant influence in shaping customers repurchase decision.

\section{Limitations and Future Research Suggestions}

Despite of the contributions, this paper acknowledges limitations. Firstly, the research was limited to the big-five personality type and omits the other personality type. Secondly, the results were based on particular city, which is Makassar. It is difficult to generalize our findings, but as this study was only sought for an in-depth understanding for customers' meaning in their experience of repurchase decisionmaking. Future research may explore the other available types and may conduct similar research in any other city or cultural settings, as Indonesia is a scattered island nation. Therefore, future efforts may focus in how particular cultural contexts altogether with personality type can shape customers repurchases decisions. Also, future research can explore the irrationality made by the customers in their repurchase decisions, which based on their personality types.

\section{Conclusion}

The purpose of this study was to explore the personality type on customers' purchase decisions toward an experience in repurchasing decisions. There are several factors (themes) identified in this research. They are: 1) word of mouth and social status; and 2) price. It was discovered that participants whose high level of personality traits such as Openness, Conscientiousness and Agreeableness are the ones that will tend to make repurchase decision in the culinary industry. Moreover, those with low level in dimension of Neuroticism show a substantial relationship in making repurchase decision toward service/goods in culinary industry, just to crafting their identity/social status in social media. This paper offers original contribution in the current literature as this paper acknowledges the importance of a qualitative study in exploring the relationship between personality types and customers repurchase decision.

\section{References}

Back, K. J. (2005). The effects of image congruence on customers' brand loyalty in the upper middle-class hotel industry. Journal of Hospitality \& Tourism Research, 29(4), 448-467.

Bansal, H. S., \& Voyer, P. A. (2000). Word-of-mouth processes within a services purchase decision context. Journal of Service Research, 3(2), 166-177.

Barkhi, R., \& Wallace, L. (2007). The impact of personality type on purchasing decisions in virtual stores. Information Technology and Management, 8(4), 313-330.

Barrick, M. R., \& Mount, M. K. (1991). The big five personality dimensions and job performance: A metaanalysis. Personnel Psychology, 44(1), 1-26.

Bellamy, A., \& Becker, J. (2015). An exploratory analysis of the relationships between personality characteristics and the perceptions of virtual merchandising. Open Journal of Social Sciences, 3(03), 119.

Chinomona, R., \& Maziriri, E. T. (2017). The influence of brand awareness, brand association and product quality on brand loyalty and repurchase intention: A case of male consumers for cosmetic brands in South Africa. Journal of Business and Retail Management Research, 12(1), 234-242.

Creswell, J. W. (2013). Qualitative Inquiry and Research Design: Choosing among Five Approaches (3rd Ed.). Los Angeles, CA: Sage Publications.

Fang, Y. H., Chiu, C. M., \& Wang, E. T. (2011). Understanding customers' satisfaction and repurchase intentions: An integration of IS success model, trust, and justice. Internet Research, 21(4), 479-503.

Frank, B., Enkawa, T., \& Schvaneveldt, S. J. (2014). How do the success factors driving repurchase intent differ between male and female customers? Journal of the Academy of Marketing Science, 42(2), 171-185.

Gosling, S. D., Rentfrow, P. J., \& Swann, W. B. (2003). A very brief measure of the Big-Five personality domains. Journal of Research in personality, 37(6), 504-528.

Haeruddin, M. I. M., \& Natsir, U. D. (2016). The cat's in the cradle: 5 Personality Types' Influence on Work-Family conflict of nurses. Economics \& Sociology, 9(3), 99-109.

Haeruddin, M. I. M. (2017). Should I stay or should I go? Human Resource Information System implementation in Indonesian public organizations. European Research Studies, 20(3A), 989. 
Han, H., \& Ryu, K. (2012). The theory of repurchase decision-making (TRD): Identifying the critical factors in the postpurchase decision-making process. International Journal of Hospitality Management, 31(3), 786-797.

Hasyim, C., \& Unde, A. (2016). The promotion of seafood culinary tourism in Makassar [Promosi wisata kuliner seafood di Makassar]. KAREBA: Jurnal Ilmu Komunikasi, 1(3), 313-326.

Hellier, P.H., Geursen, G.M., Carr, R.A \& Rickard, J.A 2003. Customer repurchase intention: A general structural equation model, European Journal of Marketing, 37(11/12), 1762 - 1800.

Jefry, K.L.S., \& Aldianto, L. (2012) Brand equity improvement in Makassar resto. The Indonesian Journal of Business Administration. 1(3), 152-158.

Kim, H. W., \& Gupta, S. (2009). A comparison of purchase decision calculus between potential and repeat customers of an online store. Decision Support Systems, 47(4), 477-487.

Kotler, P. (2012). Marketing Management, millennium edition: Custom Edition for University of Phoenix.

Kotler, P., Keller, K., Koshy, A., \& Jha, M. (2009). Marketing management, (South Asian Perspective), Dorling Kindersley (India) Pvt. Ltd. Licensees of Pearson Education in South Asia.

Marwick, A., \& Boyd, D. (2011). To see and be seen: Celebrity practice on Twitter. Convergence, 17(2), $139-158$.

McCrae, R. R \& John, O. P. (1992). An introduction to the five-factor model and its applications. Journal of Personality, $60,175-215$.

McShane, S., Olekalns, M., \& Travaglione, T. (2012). Organisational Behaviour 4e: Emerging Knowledge. Global Insights. McGraw-Hill Education Australia.

Mulyanegara, R. C., Tsarenko, Y., \& Anderson, A. (2009). The Big Five and brand personality: Investigating the impact of consumer personality on preferences towards particular brand personality. Journal of Brand Management, 16(4), 234-247.

Pine, B. J., \& Gilmore, J. H. (1998). Welcome to the experience economy. Harvard Business Review, 76, 97-105.

Saunders, M. Lewis, P. and Thornhill, A. (2012). Research Methods for Business Students. London: Pearson.

Seiders, K., Voss, G. B., Grewal, D., \& Godfrey, A. L. (2005). Do satisfied customers buy more? Examining moderating influences in a retailing context. Journal of Marketing, 69(4), 26-43.

Setiawan, I., Andjarwirawan, J., \& Handojo, A. (2013). The implementation of Android based application of Makassar tourism in Makassar City [Aplikasi Makassar tourism pada kota Makassar berbasis android]. Jurnal Infra, 1(2), pp-156.

Spreng, R. A., Harrell, G. D., \& Mackoy, R. D. (1995). Service recovery: Impact on satisfaction and intentions. Journal of Services Marketing, 9(1), 15-23.

Suki, N. M. (2013). Green awareness effects on consumers' purchasing decision: Some insights from Malaysia. International Journal of Asia-Pacific Studies, 9(2).

Van Vaerenbergh, Y., Larivière, B., \& Vermeir, I. (2012). The impact of process recovery communication on customer satisfaction, repurchase intentions, and word-of-mouth intentions. Journal of Service Research, 15(3), 262-279.

Vázquez-Casielles, R., Iglesias, V., \& Varela-Neira, C. (2017). Co-creation and service recovery process communication: Effects on satisfaction, repurchase intentions, and word of mouth. Service Business, 11(2), 321343.

Wardoyo, A. \& Reza, N.Z., (2016). Arrangement interior design on Serela grand hotel in Makassar with the idea of the traditional concept tourism and business. International Journal of Contemporary Applied Sciences, 3(1), 434-456.

Wayne, J. H., Musisca, N., \& Fleeson, W. (2004). Considering the role of personality in the work-family experience: Relationships of the big five to work-family conflict and facilitation. Journal of Vocational Behavior, 64, 108-130. 